\title{
The impact of unemployment insurance on reinsertion wages in 2015 in the rural environment of Brazil
}

\author{
O impacto do seguro desemprego sobre os salários de reinserção \\ em 2015 no meio rural do Brasil
}

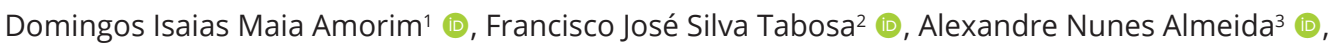
Pablo Urano de Carvalho Castelar ${ }^{2}$ (1)

\author{
${ }^{1}$ Programa de Pós-graduação em Economia Aplicada, Universidade de São Paulo (USP), Piracicaba (SP), Brasil. \\ E-mail: domingos_isaias@usp.br \\ ¿Universidade Federal do Ceará (UFC), Fortaleza (CE), Brasil. E-mail: franzetabosa@ufc.br; pcastelar@ufc.br \\ 3Universidade de São Paulo (USP), Piracicaba (SP), Brasil. E-mail: alex.almeida@usp.br
}

\begin{abstract}
How to cite: Amorim, D. I. M., Tabosa, F. J. S., Almeida, A. N., \& Castelar, P. U. C. (2023). The impact of unemployment insurance on reinsertion wages in 2015 in the rural environment of Brazil. Revista de Economia e Sociologia Rural, 61(1), e242480. https://doi.org/10.1590/1806-9479.2021.242480
\end{abstract}

\begin{abstract}
This work sought to provide new evidence on the impact of the Brazilian Unemployment Insurance Program (Programa Seguro-Desemprego) on the reinsertion wages of its beneficiaries, considering the Brazilian rural environment. Datafrom the National Household Sample Survey (Pesquisa Nacional por Amostra de Domicílios- PNAD) of 2015 was used, as well as the Sharp model discontinuity regression method. The results showed a positive effect on the reinsertion wages of individuals who participated in the Unemployment Insurance Program in rural Brazil. When disaggregating by Brazilian regions, the Southeast region had a greater positive effect on reinsertion wages, while the Midwest region has a negative effect on workers who participated in the Unemployment Insurance Program. Among the main conclusions, it is a fact that the Unemployment Insurance program had a positive effect for Brazilian formal rural workers residing in the Southeast of the country, but a negative effect for those residing in the Center-West region of Brazil.
\end{abstract}

Keywords: Brazilian Unemployment Insurance Program, discontinuity regression, rural environment.

Resumo: Este trabalho buscou fornecer novas evidências sobre o impacto do Programa SeguroDesemprego sobre o salário de reinserção de seus beneficiários, considerando o ambiente rural brasileiro. Foram utilizadas informações da Pesquisa Nacional por Amostra de Domicílios - PNAD de 2015, bem como o método de regressão de descontinuidade do modelo de Sharp. Os resultados mostraram efeito positivo sobre os salários de reinserção das pessoas que participaram do Programa Seguro-Desemprego no Brasil rural. Na desagregação por regiões brasileiras, a região Sudeste teve maior efeito positivo sobre os salários de reinserção, enquanto a região Centro-Oeste teve efeito negativo sobre os trabalhadores que participaram do Programa Seguro-Desemprego. Dentre as principais conclusões tem-se que o programa Seguro-desemprego apresentou efeito positivo para empregados rurais formais brasileiros que residem no Sudeste do país, porém efeito negativo para os residentes na região Centro-Oeste do Brasil.

Palavras-chave: Programa Brasileiro de Seguro-Desemprego, regressão descontínua, ambiente rural.

\section{INTRODUCTION}

The unemployment insurance program (Programa Seguro Desemprego - PSD) in Brazil has been used as a source of temporary income, allowing an unemployed worker to be more selective in the "choice" of the next job, while at the same time, opening up new opportunities to improve their professional training (Balbinotto Neto \& Zylberstajn, 2002; Barros et al., 2002). However, the program is not without its critics, mainly due to its irregular standardization of the distribution of benefits and its adverse effects, often being, in many people's view, an incentive to unemployment and idleness (Balestro \& Marinho, 2010). 
According to Barros et al. (2002), unemployment insurance in Brazil represents a subsidy to the search for a better job to which a worker would have access only when dismissed without just cause. From that perspective, the program encourages induced dismissal, especially in periods of economic recovery, and this decrease in the length of work relationships has a negative correlation on investments in specific human capital, productivity and wage levels.

Seeking to reverse a possible negative correlation between unemployment insurance and investment in human capital, Chahad (2000) makes some suggestions, among them, to promote, compulsorily, for workers to receive the insurance value, and professional training for the beneficiaries, which would enable a higher level of human capital and possibly a reintegration into the job market with a higher wage level, since receiving this benefit would become a signal for worker productivity, while at the same time subsidizing their basic needs until their reallocation in the job market.

The hypothesis proposed here is that unemployment insurance contributes positively to increasing the reinsertion wages of unemployment program beneficiaries in Brazilian rural environment. The way in which social programs are constituted has been providing an increasing range of questions, mainly regarding efficiency, which also includes workers from Brazilian rural environment where the level of formalization is almost always considered low.

The main objective is to investigate whether there is an effect of the benefit on the reintegration wages of Brazilian workers who are in an employment relationship in Brazilian rural area, and whether the relationship between the unemployment benefit and the reinsertion wage is positive, as proposed by the theoretical perspective of the Theory of Human Capital and labor supply.

In addition, the incentives created by an excessively benevolent unemployment insurance system can generate distortions that end up making the program less effective and generating inefficiency in the allocation of resources. The concern with the design of the programs is as important as their very existence, because it is from there that the correct incentives are generated, motivating behavior which is considered to be appropriate by society (Camargo, 2004).

In order to test the aforementioned hypothesis, a technique widely used in Economics, Political Science, and many other social, behavioral, biomedical and statistical sciences is applied. Lee (2008) reports that the Regression Discontinuity design (RDD) with added covariates is considered one of the most adequate, credible, non-experimental strategies, within the framework of causal inference, with the requirement of "balanced" covariates in the cutoff being the condition enough more natural and relevant ${ }^{1}$.

To date, in Brazil, we are unaware of any work that provides evidence about the impact of the country's unemployment insurance program on the reinsertion wages of its beneficiaries, specifically considering Brazilian rural environment, for agricultural and non-agricultural occupations. For such purposes, we adopt the Sharp model discontinuity regression method. The focus is on the rural environment of the country, because it displays different characteristics than the urban area. For instance, rural workers tend to have a higher turnover rate ${ }^{2}$ than urban workers, particularly for the seasonal aspects of agricultural production, as well as being more susceptible to sudden unemployment because of volatility in the prices of agricultural commodities, where employers are eager to reduce costs in adverse scenarios of international market given that Brazil has been a price taker.

This work consists of five sections, including this introduction. In the second section, a brief literature review on unemployment insurance programs will be presented at an international level, and specifically considering Brazil. The third section discusses the methodology, based

1 The RDD with added covariates methods is discussed in the empirical strategy section.

2 See, for example, Silva Filho et al. (2014). 
on the data and the discontinuity regression method. In the fourth section, the analysis and discussion of the model results estimated for rural areas are presented. Lastly, concluding remarks are made.

\section{UNEMPLOYMENT INSURANCE PROGRAM IN BRAZIL AND REINSERATION WAGES}

\subsection{Search for employment, unemployment insurance and reinsertion wage}

Theories that seek to understand unemployment flourished in the mid-1980s and 1990s (Fitzgerald, 1998). The incorporation of simple observations in the research at points where the theory of labor market still presented inconsistencies has resulted in rich sets of models that have helped not only to understand how unemployment responds to various policies and regulations, but also to better understand other markets.

A model of job search is presented by Fitzgerald (1998), who analyzes how the area decision of an unemployed worker affects not only their employment decisions but also the general level of unemployment. Subsequently, the source and nature of data are analyzed ${ }^{3}$. Initially, the model focuses on the decision of an unemployed worker to accept a job offered or to continue looking for a better job. Among the attributes, the model provides a simple framework for capturing many of the central ideas on which job search theory is based, as well as interesting economic insights.

The model presented by the author suggests that workers seek to maximize the expected present value of their lifetime income, which is written as:

$$
E \sum_{t=0}^{\infty} \beta^{t} y_{t}
$$

where $\beta$ is the discount fator between 0 and 1 and $y_{t}$ denotes the income of the worker in period $t$. Is is considered that $\left(y_{t}=w^{u}\right)$ if the worker is unemployed, and $\left(y_{t}=w\right)$ if the worker is employed with $w$ wage. Thus, factor $\beta$ determines the rate in which workers discount their future earnings, and can be written as $\frac{1}{1+r}$, where $r$ is the real interest rate. As the workers presented in the model have time tending to $\infty$, this assumption can be considered as an approximation of the case in which the workers have many periods to live.

Now, considering the problem of the unemployed worker's decision to evaluate a wage offer $w$, his decision will depend on how the current offer compares to other offers that can be received. If the chances of receiving a substantially better offer in the next period were considerable, then the individual may choose to reject the current offer in the expectation of receiving a better offer in the near future.

The problem of the unemployed worker's decision featured in Fitzgerald (1998) uses the following notation; consider $v^{\text {wait }}(w)$ as the expected present value of income if the individual rejects a wage offer $w$ and waits for a better offer, $v^{\text {accept }}(w)$ if the expected present value of income is accepted in $w$, and $v^{\text {offer }}$ ( $w$ ) the expected present value of income when a wage offer $w$ is received. Each of these functions presupposes that the unemployed worker will behave in a way to optimize in future periods, in order to maximize the expected income as presented in Equation 1.

The function of rejecting an offer and waiting for a better offer is given by, Equation 2:

\footnotetext{
${ }^{3}$ In addition to the work of Fitzgerald (1998), we used the work of Sargent (1987), which provides a more advanced overview of job search theory.
} 
$v^{\text {wait }}(w)=w^{u}+\beta \mathrm{E} v^{\text {offer }}$

Where $\mathrm{E} v^{\text {offer }}$ is the expected value of $v^{\text {offer }}$. Being the expected value included in the Unemployment Insurance subsidy that the worker receives monthly, plus the discount of the expected value of a new wage offer in the next period. It is important to highlight that $v^{\text {wait }}(w)$ is a constant, that Fitzgerald (1998) describes as $v^{\text {wait }}$, since $\mathrm{E} v^{\text {offer }}$ does not vary with $w$. This reflects the fact that the next period's wage offer is independent of the offer of the current period, so the value of rejecting an offer and waiting for a new offer is the same regardless of the offer of this period. The value of accepting a $w$ wage offer is:

$v^{\text {accept }}(w)=w+\beta \alpha \mathrm{E} v^{o f f e r}+\beta(1-\alpha) v^{a c c e p t}(w)$

Thus, the worker accepting a wage offer, he or she will receive the income in this period. At the end of the period, that individual will be employed with probability $\alpha$, in which case the worker receives the discounted expected value of receiving a new offer in the following period, $\beta \AA v^{\text {offer }}$, or will continue to work with probability $(1-\alpha)$, in which case that individual receives the discounted value of accepting the same wage offer in the following period, $\beta v^{a c c e p t}(w)$ income as presented in Equation 3. Thus, the equation can be rewritten as:

$v^{\text {accopt }}(w)=\frac{w+\beta \alpha \mathrm{E} v^{o f f e r}}{1-\beta(1-\alpha)}$

Through Equation 4 it can be noticed that $v^{\text {accept }}(w)$ linearly increases with $(w)$. According to Fitzgerald (1998), the problem for the worker with an offer at hand is to decide whether to accept the offer, with value $v^{\text {accept }}$, or to reject it, with value $v^{\text {wait }}$. The value of having an offer at hand is given by the following equation:

$v^{o f f e r}(w)=\max \left\{v^{\text {accept }}(w), v^{\text {wait }}\right\}$

It should be noted that offers will be accepted only when the acceptance is more beneficial to the worker than waiting for a better offer. That is, the worker evaluates labor supply according to the wage offered and compares it to the reserve (or waiting) wage. When the wages offered are greater than the waiting value, the worker accepts the new job, otherwise he or she continues to wait for a better opportunity. For Fitzgerald (1998), the solution to that problem is characterized by functions $v^{\text {offer }}(w)$ and $v^{\text {accept }}(w)$, and a constant $v^{\text {wait }}(w)$, which satisfies Equations 3, 4 and 5.

Solving the reservation wage problem (considered here to be the unemployment insurance benefit), the reservation wage $w^{r}$ is the value of $w$ which satisfies, income as presented in Equation 6:

$v^{\text {accept }}\left(w^{r}\right)=v^{\text {wait }}$

Using Equations 2 and 4,

$\frac{w^{r}+\beta \alpha \mathrm{E} v^{\text {offer }}\left(w^{r}\right)}{1-\beta(1-\alpha)}=w^{u}+\beta \alpha \mathrm{E} v^{\text {offer }}\left(w^{r}\right)$ 
The Equation 7 states that reinsertion wage is identified as the wage in which the value of accepting the wage offer (left side of the equation) is equal to the value of rejecting the offer (right side). That is, the reinsertion wage is the wage in which the worker is only indifferent between accepting or rejecting the offer. In order to solve the problem for the reintegration wage, it is necessary to attribute a function to it, which can be written as:

$\mathrm{E} v^{\text {offer }}\left(w^{r}\right)=\left(\frac{1}{1-\beta}\right)\left[\frac{w^{u}+s\left(\bar{w}-w^{r}\right)^{2}}{2(\bar{w}-\underline{w})}\right]$

Using Equation 8 to substitute Ev $v^{\text {offer }}$ in Equation 7, we obtain a single equation (Equation 9) for $w^{r}$ :

$w^{r}=w^{u}+\left[\frac{\beta(1-\alpha)}{1-\beta(1-\alpha)}\right] \frac{\left(\bar{w}-w^{r}\right)^{2}}{2(\bar{w}-\underline{w})}$

However,.$w^{r}$. appears in both sides of the equation. In order to simplify the notation, Fitzgerald (1998) defines a new function as being, Equation 10:

$\phi\left(w^{r}\right)=\left[\frac{\beta(1-\alpha)}{1-\beta(1-\alpha)}\right] \frac{\left(\bar{w}-w^{r}\right)^{2}}{2(\bar{w}-\underline{w})} \alpha$

which is the second term on the right-hand side of Equation 9. This function can be interpreted as the expected benefit of obtaining a new wage when the unemployed worker has an offer at hand. It is important to note that the function is decreasing in $w^{r}$, indicating that the expected earnings of a new salary decrease as $w^{r}$ increases. Given $w^{r}$ defined with $w$, this function will be 0 , reflecting the fact that there can be no gain in a new offer since $w$ is the highest possible wage. Equation 9 can be rewritten thus:

$w^{r}=w^{u}+\phi\left(w^{r}\right)$

Equation 11 determines the value of wage accepted by the worker based on all parameters of the model, including unemployment insurance and reinsertion wage. The left side can be understood as the benefit of accepting a wage offer at the reserve wage level. The right side can be considered as the value of rejecting the offer and waiting for a new one. It includes the value of the unemployment insurance benefit $w^{u}$ plus the expected gain of a new period. Thus, the expected gain of receiving additional wage offers depends on how selective the person is. The more selective the person is, the lower the chances of getting an offer.

Fitzgerald (1998) points out that the reserve wage behavior of the unemployed worker, in this model, is observable in the "real world" behavior of individuals, where in each period, many workers choose to continue their job searches, even if they can accept low-paid jobs. This is probably because there is an expectation that they will find a better job offer eventually.

\subsection{The Programa Seguro-Desemprego (PSD) Unemployment Insurance Program in Brazil}

Created in Brazil in 1986, the historical background of Programa Seguro-Desemprego (PSD) unemployment insurance program dates from the Federal Constitution of 1946 (art. 157, inc. XV) as "assistance to the unemployed". However, only with the enactment of Law No. 4,923, of 
December 23, 1965, the provision was regulated, constituting a financial assistance in cases of total or partial shutdown of companies with economic difficulties (Balestro \& Marinho, 2010). Thus, there was a limitation of the benefit to workers of large companies and union members, since the payment depends on a formal request from the union, by sending lists of beneficiaries with the respective documentation.

The embryo of the PSD program originates from Decree-Law No. 2,284 of March 10, 1986. With the purpose of "providing temporary financial assistance to unemployed workers due to unfair dismissal or total or partial interruption of the employer's activities. These funds came from the Treasury and were subject to cash difficulties, especially relevant in the context of the growing public debt of the $1980 \mathrm{~s}^{4}$.

Only with the 1988 Constitutionunemployment insurance in the country became stable in its financing, with the collection of the Social Integration Program (Programa de Integração Social - PIS) and funds from the Public Service Employee Savings Program (Programa de Patrimônio do ServidorPúblico- PASEP) being redirected, establishing the allocation of resources to fund unemployment insurance and enabling the creation of the Workers' Support Fund (Fundo de Amparo ao Trabalhador- FAT) (Balestro \& Marinho, 2010). Following FAT legislation, at least forty percent of the funds would be allocated to economic development programs, through the National Bank for Economic and Social Development (Banco Nacional de Desenvolvimento Econômico e Social - BNDES).

The legal framework of PSD, in place since 1994, holds that the program anticipates what would be the overcoming of a trade-off between social protection and economic efficiency such as the integration between unemployment insurance and labor intermediation and professional qualification. This economic efficiency can be observed through two different aspects, as discussed by Balestro \& Marinho (2010), being the qualification associated with gains in productivity of workforce, especially in more general skills in which employers would not be willing to invest resources, and the second aspect being a more efficient job market.

\subsection{Empirical Evidence on Unemployment Insurance Programs}

The main objective of the PSD unemployment insurance program is to protect individuals against the loss of wage income. That said, different unemployment insurance systems in many countries aim to provide short-term income support to involuntarily unemployed workers while looking for work.

While these benefits increase the well-being of risk-averse individuals affected by adverse shocks in employment by softening consumption, on the other hand, at the same time, unemployment insurance can induce a moral hazard 5 and create disincentives for rapid reintegration into the job market (Ahn, 2018). As discussed by Chetty \& Finkelstein (2013) and Tatsiramos \& Van Ours (2014), the payment of the insurance benefit can make unemployed individuals look for new jobs, but less so than in the absence of the benefit, and it is also possible that the opportunities for employment decrease with the duration of a period of unemployment, as discussed by Addison and Blackburn (2000), which the authors argue can be the result of stigmatization or the depreciation of human capital, which potentially increases the duration of unemployment.

In developed countries, seeking to avoid potential disincentives in job searching, policy makers have considered and introduced additional services for benefit seekers, including

\footnotetext{
${ }^{4}$ See Castro \& Souza (1985) and Fishlow (1986).

${ }^{5}$ Which occurs when an insured person behaves in such a way as to increase the probability of the occurrence of an event that is insured to receive payment of the indemnity. For more, see: Seo (2016), Microbehavioral Econometric Methods - Chapter 7 - Modeling Risk, Perceptions, and Uncertainties with Microbehavioral Methods.
} 
assistance and job search monitoring (Ahn, 2018). The empirical literature on programs such as those which offer unemployment insurance that affects the rate of unemployment among workers is abundant.

Beginning in the mid-1990s, Atkinson \& Micklewright (1991) and Pedersen \& WestergardNielsen (1993) used cross-sectional data at the individual level and concluded that the effects of such benefits are generally significant in the US and UK studies, while most of the research in Continental Europe find insignificant or weak effects.

Authors such as Card \& Levine (2000), Carling et al. (2001), Lalive (2008) and Schmieder et al. $(2012 a, b)$, present an overview of recent works on the effects of the unemployment insurance programs of different countries.

More specifically, concerning the benefit to reinsertion wages, the work of Card et al. (2007) is worth highlighting, where the authors not only do an extensive literature review on the subject, but also explore a discontinuity in the relationship between work experience and the right to the benefit for Austrian workers. Their main finding is that the way in which unemployment spells are measured has a significant effect on the magnitude of the spike at exhaustion both in existing studies and in the data for Austria.

Uusitalo \& Verho (2010), who used a change in policy in Finland to analyze the effect of the unemployment program's replacement rate on the duration of unemployment, found that the change in the benefit structure reduced the chances of reemployment by $17 \%$, on average. Schmieder et al. (2012b), implementing a model of discontinuity with German data on workers aged 40 to 49, found that for each additional month of unemployment insurance reduction, the duration of unemployment increases on average 0.10 and 0.13 months.

Using a Hungarian reform as an identification strategy for the RDD, Lindner \& Reizer (2016) found that decreasing unemployment insurance benefits dynamically, keeping global benefit amounts constant, reduces the duration of unemployment and increases wages for reinsertion.

In Brazil, to date, only Teixeira \& Balbinotto Neto (2016) evaluated the influence of Brazilian unemployment insurance program on the reinsertion wages of its beneficiaries. The authors analyze data for the period between 2007 and 2009, from the National Household Sample Survey (Pesquisa Nacional por Amostra de Domicílio- PNAD) for all regions of the country. Using discontinuous regression methods, as well as propensity score matching, the authors found that the Brazilian program was not sufficient to influence the beneficiaries' reinsertion wage. However, as mentioned earlier, no research has done the same for the rural job market.

\section{METHODOLOGY}

\subsection{Data}

The data used in this work come from the National Household Sample Survey (Pesquisa Nacional por Amostra de Domicilio- PNAD) in 2015, specifically the annual PNAD, considering residents of Brazilian rural environment. The use of the 2015 PNAD is justified because it is the last PNAD that allows us to capture whether the individual received unemployment insurance after leaving their last formal job. After 2015, IBGE started to adopt another methodology, the Continuous PNAD, and with it a new questionnaire, which makes it impossible to capture such information.

The database provides important and specific information, related to workers who left a job within a year. The data can also be organized, then, in two specific aspects: the number of months in which the worker remained in their previous job, with expected results between one month to 11 months; and if the individual received unemployment insurance after that worker left their previous job. 
Table 1 below shows the number of months that the individual worked before becoming unemployed and getting a new job. Considering that the individual needs to work at least 6 months to be eligible for PSD unemployment insurance program, the table features those who would be eligible for the insurance benefit ( 6 or more months), and the counterfactuals (less than 6 months in the last job).

Table 1- Distribution (\%) of employment transitions - Number of months an individual worked before becoming unemployed - 2015

\begin{tabular}{ccccccc}
$\begin{array}{c}\text { Months / } \\
\text { Region }\end{array}$ & North & Northeast & Southeast & $\begin{array}{c}\text { Center- } \\
\text { West }\end{array}$ & South & Brazil \\
$\mathbf{1}$ & 14.05 & 40.80 & 26.94 & 7.80 & 10.41 & 100 \\
$\mathbf{2}$ & 6.91 & 48.37 & 27.56 & 5.27 & 11.89 & 100 \\
$\mathbf{3}$ & 11.32 & 44.35 & 25.35 & 8.58 & 10.40 & 100 \\
$\mathbf{4}$ & 10.29 & 30.91 & 31.66 & 11.32 & 15.83 & 100 \\
$\mathbf{5}$ & 13.72 & 36.03 & 24.32 & 9.86 & 16.07 & 100 \\
$\mathbf{6}$ & 13.31 & 45.35 & 14.13 & 11.74 & 15.47 & 100 \\
$\mathbf{7}$ & 11.86 & 27.04 & 29.40 & 8.50 & 23.21 & 100 \\
$\mathbf{8}$ & 7.20 & 25.84 & 30.68 & 12.06 & 24.22 & 100 \\
$\mathbf{9}$ & 3.76 & 48.00 & 21.52 & 8.88 & 17.84 & 100 \\
$\mathbf{1 0}$ & 7.31 & 41.70 & 27.51 & 11.37 & 12.11 & 100 \\
$\mathbf{1 1}$ & 7.36 & 25.64 & 24.00 & 18.48 & 24.54 & 100 \\
Total & 10.16 & 37.88 & 25.22 & 10.53 & 16.21 & 100 \\
\hline
\end{tabular}

Source: Prepared by the authors using data from the 2015 PNAD (PNAD, 2015).

Based on the sample of individuals that compose the database from the sample weights, Table 1 shows, thus, the distribution of unemployment and subsequent employment transitions; for unemployment, there are transitions at monthly intervals of up to 11 months. The window for observation of transitions is fixed at 11 months, since the total period which is possible for the observations is one year since entering involuntary unemployment. In the complete sample, the majority (51.78\%) of individuals did not meet the basic criteria to participate in the PSD unemployment insurance program, i.e., to work continuously with a formal contract for at least 6 months.

Data reveal that the Northeast region of Brazil features the largest portion of the sample (37.88\%), individuals who were involuntarily unemployed for at least one month in the reference period, followed by the Southeast region (25.22\%). Analyzing from the perspective of the months worked, there is a certain homogeneity, suggesting that the minimum time required to access the unemployment insurance program (6 months) possibly does not generate unobservable bias ${ }^{6}$.

\subsection{Discontinuous Regression: A non-parametric approach}

Given that in a non-parametric regression, the estimator is constructed according to the information obtained through data, without taking a predetermined form, the functional form itself will be estimated. From the existing procedures, the use of a local linear regression is indicated, which can be equated to a linear estimation in two intervals adjacent to the cutoff point, thus estimating the impact on a subsample within a given bandwidth. Left and right of the cutoff point (Hahn et al., 2001).

\footnotetext{
${ }^{6}$ Empirical assessments of dynamic benefits for the program beneficiary are not homogeneous. For further reading, see Lindner \& Reizer (2016) and Kolsrud et al. (2018).
} 
Based on Calonico et al. (2014), the nonparametric method makes it possible to construct robust parameters using a local polynomial regression, which fits the data structure and its proposal for assessing thresholds, smoothing dispersions and modeling functions.

In order to identify whether the Programa Seguro-Desemprego unemployment insurance program in Brazil is exercising any influence on the reinsertion wages of insured persons in rural areas, the method of discontinuous regression (RDD) was used.

The definition of causal effects used here meets the Neyman-Fisher-Rubin causal model ${ }^{7}$. Following Hahn et al. (2001), $D_{i}=\in\{0,1\}$ is defined as a binary treatment variable, $Y_{i}^{0}, Y_{i}^{1}$, the potential results, while $Y_{i}^{1}-Y_{i}^{0}$, the treatment effect on the individual. The potential results, as well as the treatment results, allows variation among individuals, that is, no constant treatment effect is assumed. $Z_{i}$ is considered a variable that influences the treatment variable discontinuously.

Literature presents two distinct designs, however, this work focuses only on one, the sharp case, where $D_{i}$ is the criteria for participation in the Unemployment Insurance Program, and changes for all individuals, at a known threshold $z_{0}$, in this case, $z_{0}=6$. In the Sharp design, Trochim (1984), defines that participation status is given by a deterministic function of $z$, Equation 12:

$D_{i}=1[Z \geq 6$ months $]$

This implies that all individuals change the program's participation status exactly $z_{0}$. Hahn et al. (2001) consider the assumption of identification as

$Y_{i}^{1}-Y_{i}^{0} \perp D_{i} \mid Z_{i}$

Consider that $Y$ is the variable of interest, the reinsertion wage, and is the "forcing" variable with a known threshold, $z_{0}$, where the likelihood of treatment, $\operatorname{Pr}(D=1 \mid Z)$, is unknown.

There are several motivations for including covariates, denoted by $к$. First, by reducing the variance, which is something well known for the parametric case. The gains in accuracy can also be achieved in the nonparametric model, as including covariables and comparing them appropriately reduces the asymptotic variance of the estimated treatment effect. Equation 13 can then be rewritten including the covariates $X$, as in Equation 14:

$Y_{i}^{1}-Y_{i}^{0} \perp D_{i} \mid X_{i}, Z_{i}$

Thus identifying the treatment effect as in Equation 15:

$$
\begin{gathered}
E\left[Y_{i}^{1}-Y_{i}^{0} \mid Z=z_{0}\right] \\
=\int\left(E\left[Y \mid D=1, X=x, Z=z_{0}\right]-E[Y \mid D=0, X=x, z\right. \\
\left.\left.=Z_{0}\right]\right) \frac{f^{+}\left(x \mid z_{0}\right)+f^{-}\left(x \mid z_{0}\right)}{2} d x,
\end{gathered}
$$

In which $E\left[Y \mid D, X, Z=z_{0}\right]$ can be estimated by a combination of the left and right sides of the threshold. It is worth mentioning that the new aspect featured in this work is the presence of additional covariates, collected in the random vector $Z_{i} \in R^{d}$, which can be continuous, discrete or mixed. Considering $Z_{i}=Z_{i}(0)\left(1-T_{i}\right)+Z_{i}(1) T_{i}$, where $Z_{i}(1)$ and $Z_{i}(0)$ denote potential covariates for each side of the cutoff. Calonico et al. (2018) highlights that researcher frequently assume that some characteristics of the marginal distributions of $Z_{i}(1)$ and $Z_{i}(0)$ are the same, close to the cutoff point or, that $Z_{i}(1)={ }_{d} Z_{i}(0)$, which is implied in the definition of a pre-treatment variable.

\footnotetext{
7 Neyman (1923), Fisher (1935) and Rubin (1978).
} 


\subsection{Manipulation test using local polynomial density}

Given a configuration where each unit in a random sample from a large population is assigned to one of two groups, the observed covariates exceed a known limit. Based on this, McCrary (2008) introduces the idea of a manipulation test in the context of a discontinuous regression (RDD). In this sense, the two possible groups are generically referred to as control and treatment groups (McCrary, 2008). The observed variable determines the group assignment, and it is generically referred to as the score. The key idea behind manipulation tests in this context is that, in the absence of systematic manipulation of the unit index around the cutoff, the density of the units should be continuous when close to this cutoff value. Thus, a manipulation test formally determines whether there is evidence of a discontinuity in unit density at the known cutoff point (Cattaneo et al., 2020). The presence of such evidence is generally interpreted as empirical evidence of self-selection or non-random classification of units into control and treatment status.

A manipulation test in this context is a hypothesis test about the continuity of density. $f($.) at cutoff point $x$. Formally, the interest is in the test problem according to Equation 16:

$$
\begin{array}{r}
\mathrm{n} H_{0}: \lim _{x \uparrow \bar{x}} f(x)=\lim _{x \downarrow \bar{x}} f(x) \\
H_{1}: \lim _{x \uparrow \bar{x}} f(x) \neq \lim _{x \downarrow \bar{x}} f(x)
\end{array}
$$

To construct a statistic for this hypothesis testing problem, Cattaneo et al. (2017) were followed and the density was estimated. $f($.) using a local polynomial density estimator based on the cumulative distribution function (cdf) of the observed sample. This estimator has several interesting properties, including the fact that it does not require pre-creation of data andit is very intuitive in its implementation.

The manipulation test statistics implemented here take the form

$$
\begin{gathered}
T_{p}(h)=\frac{\hat{f}_{+, p}(h)-\hat{f}_{-, p}(h)}{\hat{V}_{p}(h)} \\
\hat{V}_{p}^{2}(h)=\hat{v}\left\{\hat{f}_{+, p}(h)-\hat{f}_{-, p}(h)\right\}
\end{gathered}
$$

Where, in Equation 17, $T_{p}(h) \sim \mathcal{N}(0,1)$ under proper assumptions, and the notation $\hat{v}\{\}$ is used to denote some consistent estimator of the amount of population $v\{\{$.$\} Parameter h$ and the bandwidths are used to locate the estimation and inference procedures near the cutoff point $x$.

In running this test, the test statistic was constructed using a polynomial $q=3$, with equal bandwidths chosen for an unrestricted model with polynomial order $p=2$. Specifically, the chosen bands have width $\left(\hat{h}_{1, \text { comb }, p}, \hat{h}_{r, \text { comb }, p}\right)=(5,000,5,000)$ presenting an effective sample size of $N_{-}=352785$ e $N_{+}=328443$ for control and treatment groups, specifically. Manipulation test presented $T_{q}\left(\hat{h}_{1, \text { comb. }}, \hat{h}_{r, \text { comb }, p}\right)=-32.1748$, with a $p$-value of 0.0000 . Therefore, in this application, there is no statistical evidence of systematic manipulation of the running variable.

\section{RESULTS}

In order to assess the impact of the PSD unemployment insurance program on reinsertion wages of beneficiaries in the rural area of Brazil, an analysis was made of the difference in the means between the workers who received aid when they left their previous jobs, compared to the workers who did not meet the requirements for receiving the insurance benefit. 
Table 2 shows values of the tests between means, making it possible to see that the test of difference of means between the two groups was statistically significant for rural Brazil, with 95\% confidence. Thus, there are indications that there are wage differences which can be captured by tests between the average of workers who received unemployment insurance (treatment group), and those who did not (control group), with a 5\% chance of error.

Table 2 - Simple wage means test, rural Brazil - 2015

\begin{tabular}{lcccccc} 
& & & & & \multicolumn{2}{c}{ Confidence Interval } \\
\cline { 5 - 7 } \multicolumn{1}{c}{ Groups } & Observations & Mean $\mathbf{( R \$ )}$ & $\begin{array}{c}\text { Standard } \\
\text { Error }\end{array}$ & $\begin{array}{l}\text { Standard } \\
\text { Deviation }\end{array}$ & $\begin{array}{c}\text { Lower } \\
\text { Bound }\end{array}$ & $\begin{array}{c}\text { Upper } \\
\text { Bound }\end{array}$ \\
Control & 352,515 & 870.35 & 1.3044 & 774.4543 & 867.7973 & 872.9104 \\
Treatment & 328,443 & 921.83 & 1.2347 & 707.6009 & 919.4125 & 924.2525 \\
Combined & 680,958 & 895.18 & 0.9009 & 743.4053 & 893.4176 & 896.949 \\
Diff & & -51.47 & 1.8018 & & -55.0101 & -47.9471 \\
\hline
\end{tabular}

Source: Prepared by the authors using data from the 2015 PNAD (PNAD, 2015).

Kernel density function of the sample wage distribution indicates possible differences in density between wage ranges. Thus, when we analyze Figure 1, we find that there is a higher density among workers who earn around a minimum wage for the control group, while for the treatment group, the distribution is more flat. However, it also shows there is no other wage density between the two groups.

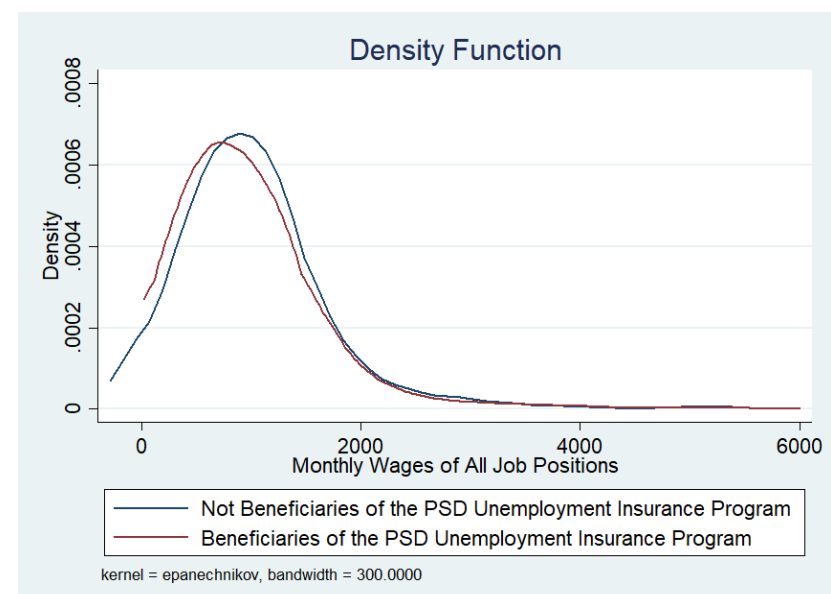

Figure 1 - Kernel estimate of sample wage density - rural Brazil - 2015. Source: Prepared by the authors using data from the 2015 PNAD (PNAD, 2015).

While there are several recent researches in literature using the RDD model (Imbens \& Lemieux, 2007, Lee \& Lemieux, 2010, DiNardo \& Lee, 2010), our focus is specifically on approaches using local polynomial nonparametric estimators, with the choice of the optimal window width according to the nature of the data and bias correction techniques, following Imbens \& Kalyanaraman (2012) and Calonico et al. (2014).

Figure 2 is designed from the method mimicking the uniformly spaced variation using spacing estimators, as shown in Table 3, composed of 681,228 complete observations, which are reproduced in the figure with evenly spaced boxes that mimic the underlying variability of data, and it is implemented using spacing estimators. Optimal window widths on both sides of the cutoff point are derived using 4th order triangular and local polynomial cores. 
Table 3 - Number of positions to estimate RDD

\begin{tabular}{lcc}
\multicolumn{1}{c}{ Cutoff point c=6 } & Left of c & Right of c \\
Number of observations & 352785 & 328443 \\
Polynomial Order & 4 & 4 \\
Chosen scale & 1,000 & 1,000 \\
Selection bins & 105 & 60 \\
Bin length & 7665 & 5074 \\
IMSE-optimal bins & 105 & 60 \\
Mimicking variance bins & 44340 & 3495 \\
Relative to IMSE-optimal & & 1 \\
Implied Scale & 1 & 0.500 \\
WIMSE variance weight & 0.500 & 0.500 \\
WIMSE bias weight & 0.500 &
\end{tabular}

Source: Prepared by the authors using data from the 2015 PNAD (PNAD, 2015).

The number of positions for control and treatment units is $\hat{J}_{-, n}=44340$ and $\hat{J}_{+, n}=3495$, respectively, implying binary lengths of 0.048 and 0.083 percentage points, respectively, while polynomial is constructed using a grade 4 polynomial, $\left[p=4\right.$ for $\hat{\mu}_{-, p, 1}(x)$ and $\left.\hat{\mu}_{+, p, 1}(x)\right]$.

The output table also informs the IMSE (ideal number of bins and the multiplicative factor (scale) associated with the number of selected bins (taking the optimal IMSE value as a reference). Lastly, IMSE weights corresponding to the chosen number of bins are presented ${ }^{8}$.

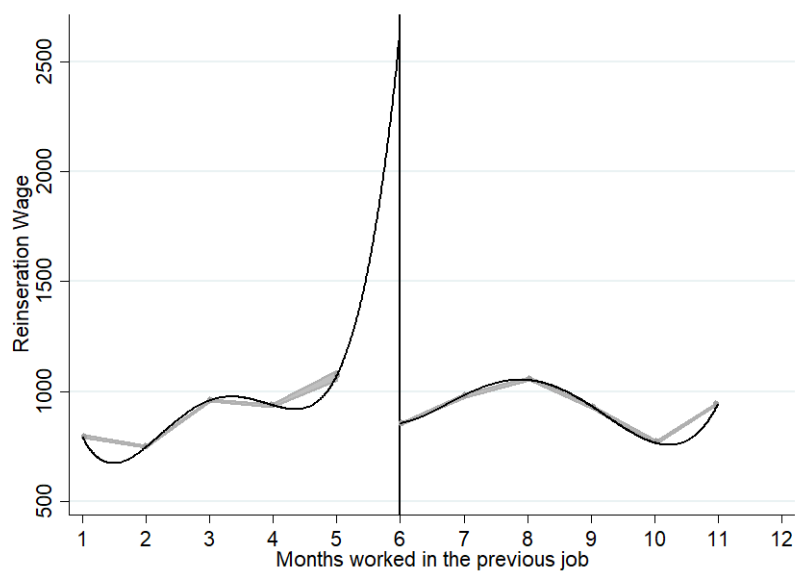

Figure 2 - RDD plot. Rural Brazil, 2015. Source: Prepared by the authors using data from the 2015 PNAD (PNAD, 2015).

In order to identify a possible discontinuity in wages between the two groups of workers, non-parametric equations are estimated. Table 4 presents the results of $\beta$ coefficients that represent the "jump" that occurs in the reinsertion wages of individuals who participated in the Brazilian unemployment insurance program.

Table 4 - Non-parametric Regressions

\begin{tabular}{lccc}
\multicolumn{1}{c}{ Method } & Coeficient & Standand Deviation & Z \\
Conventional & $-31.699 * * *$ & 3.7852 & -8.3745 \\
Bias-corrected & $171.98 * * *$ & 3.7852 & 45.4346 \\
Robust & $171.98 * * *$ & 7.6266 & 22.5500 \\
\hline Source: & &
\end{tabular}

Source: Prepared by the authors using data from the 2015 PNAD. Note: Threshold (cutoff point) used in this work is equal to six (6) months, windows of 5 and 7 months were used in order to guarantee the robustness of the model. *** $P<0.05$.

${ }^{8}$ For further details, see: Calonico et al. (2014). 
Results shown in Table 4 are similar to the average test shown in Table 2. However, with this instrument, it is possible to quantify the variation in the average wage between the two groups, controlling for different windows of length of permanence in the previous job. To guarantee the robustness of results, the \pm 1 month window is used, in other words, individuals who worked from 5 to 7 months in the reference period are considered.

Previous works on the effect of unemployment insurance programs on reinsertion wages suggest a weakly positive relationship. Our results presented in Table 4 are aligned with the works of Ehrenberg \& Oaxaca (1976), Burgess \& Kingston (1976) and Blau \& Robins (1989), who found a positive effect. On the other hand, there are some studies, such as Classen (1977), for example, in which author found no relationship between the level of benefits and reinsertion wages.

However, it is extremely important to note that the heterogeneous effects of individual's profile can promote a more efficient reinsertion in the job market for some, but not for others, as discussed by Tatsiramos (2006), Van Ours \& Vodopivec (2008) and Monte et al., (2009). These authors show that individuals participating in unemployment programs were penalized. In view of these inconclusive results in literature, and the inherent heterogeneity that exists in rural areas in Brazil, we choose to disaggregate our analysis, considering now the different regions of Brazil.

Based on the results shown in Table 5, it can be seen that the Brazilian region that had the greatest positive effect on reinsertion wages is the Southeast region of the country, which had the second highest percentage of rural workers rehired (or reinserted) in the period. It can also be observed that the Center-west region shows a negative effect for workers who participated in the Unemployment Insurance Program.

Table 5 - Non parametric regressions for each region of Brazil

\begin{tabular}{lccc}
\multicolumn{1}{c}{ Method } & Coefficient & Standard Dev. & Z \\
North Region & & & -11.4556 \\
Conventional & $-94.091 * * *$ & 8.2136 & 16.4186 \\
Bias-corrected & $134.86 * * *$ & 8.2136 & 7.5428 \\
Robust & $134.86 * * *$ & 17.879 & \\
NortheastRegion & & & -16.1344 \\
Conventional & $-93.17 * * *$ & 5.7747 & -2.2807 \\
Bias-corrected & $-13.17 * *$ & 5.7747 & -1.1677 \\
Robust & -13.17 & 11.279 & \\
SoutheastRegion & & & 61.3009 \\
Conventional & $495.51 * * *$ & 8.0832 & 101.8004 \\
Bias-corrected & $822.88 * * *$ & 8.0832 & 57.6275 \\
Robust & $822.88 * * *$ & 14.279 & \\
Center-West Region & & & -17.4023 \\
Conventional & $-220.11 * * *$ & 12.648 & -22.2058 \\
Bias-corrected & $-280.87 * * *$ & 12.648 & -11.1851 \\
Robust & $-280.87 * * *$ & 25.111 & \\
South Region & & & -15.5254 \\
Conventional & $-152.59 * * *$ & 9.8282 & 1.1835 \\
Bias-corrected & 11.632 & 9.8282 & 0.5554 \\
Robust & 11.632 & 20.945 & \\
\hline
\end{tabular}

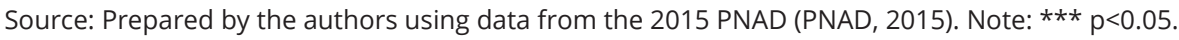




\section{CONCLUDING REMARKS}

The objective of this work was to provide evidence on the impact of Programa SeguroDesemprego(PSD) Brazilian Unemployment Insurance Program on the reinsertion wages of its beneficiaries, for the Brazilian rural environment. For that purpose, data from National Household Sample Survey (Pesquisa Nacional de Amostra por Domincílios - PNAD) from 2015 was used (specifically, the continuous PNAD); as well as the Sharp model regression discontinuity method.

Results showed that the highest density being among workers earning around a minimum wage for the control group, while for the treated group the distribution is more spread out; however, results also suggest that there is no other wage density between groups.

Another important result was the occurrence of a "jump" in the reinsertion wages of individuals who participated in the unemployment insurance program, as also found in Ehrenberg \& Oaxaca (1976), Burgess \& Kingston (1976) and Blau \& Robins (1989).

When performing a disaggregated analysis, for different Brazilian regions, the results showed that the Southeast region of the country had a greater positive effect on the reinsertion wage, which had the second highest percentage of rural workers rehired in the period. CenterWest region, on the other hand, shows a negative effect on workers who participated in the Unemployment Insurance Program.

Thus, it is suggested that the format of unemployment insurance program for individuals in Brazilian rural environment should be thought out and structured in such a way as to generate higher levels of information on the job market, as well as adding some type of human capital formation for those individuals, through qualification courses, training and retraining, as it is from this point that workers will be able to re-enter the job market in a faster, more stable and with greater wage levels.

A potential limitation of this work is the evaluation based on cross-section data, which does not make it possible to capture the effect of the program over time, as well as the influences of changes inherent to policy changes over years.

\section{REFERENCES}

Addison, J. T., \& Blackburn, L. M. (2000). The effects of unemployment insurance on postunemployment earnings. Labour economics, 7(1), 21-53.

Ahn, T. (2018). Assessing the effects of reemployment bonuses on job search: a regression discontinuity approach. Journal of Public Economics, 165, 82-100.

Atkinson, A., \& Micklewright, J. (1991). Unemployment compensation and labor Market transitions: a critical review. Journal of Economic Literatura, 29(4), 1679-1727.

Balbinotto Neto, G., \& Zylberstajn, H. (2002). Uso repetido do Seguro-Desemprego: teorias e evidências. In J. P. Z. Chahad \& R. Fernandes (Eds.), O mercado de trabalho no Brasil: políticas, resultados e desafios. São Paulo: FIPE.

Balestro, M. V., \& Marinho, D. C. N. (2010). Programa Seguro-Desemprego: o desafio para equilibrar proteção social e eficiência econômica. Revista de Políticas Públicas, 14(1), 193-201.

Barros, R. P., Corseuil, C. H., \& Foguel, M. (2002). Os incentivos adversos e a focalização dos programas de proteção ao trabalhador no Brasil. Rio de Janeiro: Instituto de Pesquisa Econômica Aplicada - IPEA.

Blau, D. M., \& Robins, P. K. (1989). Fertility, employment, and child-care costs. Demography, 26, 287-299. http://dx.doi.org/10.2307/2061526 
Burgess, P. L., \& Kingston, J. L. (1976). The impact of unemployment insurance benefits on reemployment success. Industrial \& Labor Relations Review, 30(1), 25-31. http://dx.doi. org/10.1177/001979397603000102

Calonico, S., Cattaneo, M., \& Titiunik, R. (2014). Robust data-driven inference in the regressiondiscontinuity design. The Stata Journal, 14(4), 909-946.

Calonico, S., Cattaneo, M., Farrell, M., \& Titiunikm, R. (2018). Regression discontinuity designs using covariates. Political Analysis, 20, 25-46. http://dx.doi.org/10.1162/rest_a_00760

Camargo, J. M. (2004). Política social no Brasil: prioridadeserradas, incentivosperversos. São Paulo em Perspectiva, São Paulo, 18(2), 68-77. http://dx.doi.org/10.1590/S0102-88392004000200008

Card, D., \& Levine, P. (2000). Extended benefits and the duration of UI spells: evidence from the New Jersey extended benefic program. Journal of Public Economics, 78, 107-138.

Card, D., Chetty, R., \& Weber, A. (2007). The spike at benefit exhaustion: leaving the unemployment system or starting a new job? The American Economic Review, 97(2), 113-118.

Carling, K., Holmlund, B., \& Vejsiu, A. (2001). Do benefit cuts boost job findings? Swedish evidence from the 1990s. Economic Journal, 111, 766-790. http://dx.doi.org/10.1111/1468-0297.00659

Castro, A. B., \& Souza, F. (1985). A Economia Brasileira em marcha forçada. São Paulo: Paz e Terra.

Cattaneo, M. D., Jansson, M., \& Ma, X. (2017). Manipulation testing based on density discontinuity. The Stata Journal, 18(1), 234-261.

Cattaneo, M. D., Jansson, M., \& Ma, X. (2020). Simple local polynomialdensityestimators. Journal of the American Statistical Association, 115, 1449-1455.

Chahad, J. P. Z. (2000). O seguro-desemprego no contexto do sistema público de emprego e o seu papel no combate à pobreza no caso brasileiro. In R. Henriques \& A. R. Barros (Eds.), Desigualdade e pobreza no Brasil. Rio de Janeiro: IPEA.

Chetty, R., \& Finkelstein, A. (2013). Social insurance: connecting theory to data. In A. J. Auerbach, M. S. Feldstein, R. Chetty \& E. Saez (Eds.), Handbook of public economics (pp. 111-193). Amsterdam: Elsevier.

Classen, K. (1977). The effect of unemployment insurance os the duration of unemployment and subsequente earnings. Industrial \& Labor Relations Review, 30, 438-444. http://dx.doi. org/10.2307/2523101

DiNardo, J., \& Lee, D. S. (2010). Program evaluation and research designs. Cambridge: National Bureau Of Economic Research.

Ehrenberg, R. G., \& Oaxaca, R. L. (1976). Unemployment insurance, duration of unemployment, and subsequent wage gain. The American Economic Review, 66(5), 754-766.

Fisher, R. (1935). Design of experiments. Edinburgh: Oliver e Boyd.

Fishlow, A. (1986). A economia política do ajustamento brasileiro aos choques do petróleo: uma nota sobre o período 1974/84. Pesquisa e Planejamento Econômico, 16(3), 507-550.

Fitzgerald, T. J. (1998). Introduction to the Search Theory of unemployment. Economic Review, 34(3), 2-15.

Hahn, J., Todd, P., \& Van Der Klaauw, W. (2001). Identification and estimation of treatment effects with a regression-discontinuity design. Econometrica, 69, 201-209. http://dx.doi. org/10.1111/1468-0262.00183

Imbens, G., \& Kalyanaraman, K. (2012). Optimal bandwidth choice for the regression discontinuity estimator. The Review of Economic Studies, 79(3), 933-959. http://dx.doi.org/10.1093/ restud/rdr043 
Imbens, G., \& Lemieux, T. (2007). Regression discontinuity designs: a guide to practice. Journal of Econometrics, 142, 615-635. http://dx.doi.org/10.3386/w13039

Kolsrud, J., Landais, P. C., \& Spinnewijn, J. (2018). The optimal timing of unemployment benefits: Theory and evidence frow Sweden. The American Economic Review, 108(4-5), 985-1033. http://dx.doi.org/10.1257/aer.20160816

Lalive, R. (2008). How do extended benefits affect unemployment duration? A regression discontinuity approach. Journal of Econometrics, 142(2), 785-806.

Lee, D. (2008). Randomized experiments from non-random selection in U.S. Journal of Econometrics, 142, 675-697. http://dx.doi.org/10.1016/j.jeconom.2007.05.004

Lee, D. S., \& Lemieux, T. (2010). Regression discontinuity designs in Economics. Journal of Economic Literature, 48(2), 281-355. http://dx.doi.org/10.1257/jel.48.2.281

Lindner, A., \& Reizer, B. (2016). Frontloading the unemployment benefic: an empirical assessment. American Economic Journal. Applied Economics, 12(3), 140-174.

McCrary, J. (2008). Manipulation of the running variable in the regression discontinuity design: a density test. JournalofEconometrics, 142, 698-714.

Monte, P. A., Araujo Junior, I. T., \& Pereira, M. L. (2009). O custo salarial da duração do desemprego para o trabalhador. Economia e Sociedade Brasileiras, 19(3), 443-470.

Neyman, J. (1923). On the application of probability theory to agricultural experiments. Statistical Science, 5, 463-480. http://dx.doi.org/0.1214/ss/1177012032

Pedersen, P., \& Westergard-Nielsen, N. (1993). Unemployment: a review of the evidence from panel data. OECD Economic Studies, 20, 65-114. http://dx.doi.org/10.25428/18242979/201802-231-248

PNAD - IBGE (2015). Pesquisa nacional por amostra de domicílios. Rio de Janeiro: IBGE.

Rubin, D. (1978). Bayesian inference for causal effects: the role of randomization. Annals of Statistics, 6(1), 34-58. http://dx.doi.org/10.1214/aos/1034276631

Sargent, T. J. (1987). Dynamic Macroeconomic Theory. Cambridge, Mass.: Harvard University Press.

Schmieder, J., Von Wachter, T., \& Bender, S. (2012a). The long-term Effects of unemployment insurance extensions on employment. The American Economic Review, 102, 514-519.

Schmieder, J., Von Wachter, T., \& Bender, S. (2012b). The effects of extended unemployment insurance over the business cycle: Evidence from regression discontinuity estimates over 20 years. The QuarterlyJournalofEconomics, 127(2), 701-752.

Silva Filho, L. A., Mariano, J., \& Queiroz, S. N. (2014). Emprego formal e rotatividade no mercado de trabalho agropecuário no Nordeste: 2000-2001 e 2009-2010. PerspectivaEconômica, 10(1), 39-51. http://dx.doi.org/10.4013/pe.2014.101.04

Tatsiramos, K. (2006). Unemployment insurance in Europe: unemployment duration and subsequent employment stability. Journal of the European Economic Association, 7, 12251260. http://dx.doi.org/10.1162/JEEA.2009.7.6.1225

Tatsiramos, K., \& Van Ours, J. C. (2014). Labor market effects of unemployment insurance design. Journal of Economic Surveys, 28(2), 284-311. http://dx.doi.org/10.1111/joes.12005

Teixeira, G., \& Balbinotto Neto, G. (2016). Seguro-desemprego brasileiro e salário de reinserção: análise empírica com regressão com descontinuidade e propensity score matching. Nova Economia, Belo Horizonte, 26(3), 943-980. http://dx.doi.org/10.1590/0103-6351/2215 
Trochim, W. (1984). Research design for program evaluation: the regression discontinuity approach. Beverly Hills: Sage.

Uusitalo, R., \& Verho, J. (2010). The effect of unemployment benefits on re-employment rates: Evidence from the Finnish unemployment insurance reform. Labour Economics, 17(4), 643-654. http://dx.doi.org/10.1016/j.labeco.2010.02.002

Van Ours, J. C., \& Vodopivec, M. (2008). Does reducing unemployment insurance generosity reduce job match quality? Journal of Public Economics, 92(3), 684-695. http://dx.doi. org/10.1016/j.jpubeco.2007.05.006 